\title{
PENINGKATAN PEMAHAMAN TENTANG ENTREPRENEURSHIP MELALUI BIMBINGAN KELOMPOK
}

\author{
Indiati $^{(1)}$, Astiwi Kurniati( ${ }^{(2)}$, Nofi Nur Yuhenita ${ }^{(3)}$ \\ Program Studi Bimbingan dan Konseling \\ Fakultas Keguruan dan Ilmu Pendidikan \\ Unversitas Muhammadiyah Magelang \\ E-mail: syatotoindiati@gmail.com
}

\begin{abstract}
Abstrak
Penelitian ini bertujuan untuk mengetahui keefektifan layanan bimbingan kelompok dalam meningkatkan pemahaman entrepreneurship di kalangan mahasiswa program studi bimbingan dan konseling UM Magelang, dengan jenis penelitian eksperimen. Pengumpulan data dilaksanakan denngan skala pemahaman entrepreneurship. Hasil penelitian menunjukkan bahwa terjadi peningkatan pemahaman entrepreneurship dikalangan mahasiswa program studi bimbingan dan konseling UM Magelang sebanyak $91,4 \%$.
\end{abstract}

Kata kunci: entrepreneurship, bimbingan kelompok

\section{Abstract}

This study aims to determine the effectiveness of group guidance services in improving the understanding of entrepreneurship among the students of the study program guidance and counseling UM Magelang, with the type of experimental research. Data collection is carried out with the scale of understanding of entrepreneurship. The results showed that there was an increase in understanding of entrepreneurship among students of guidance and counseling program of UM Magelang as much as $91.4 \%$.

Keywords: entrepreneurship, group guidance

\section{Info Artikel}

Diterima Maret 2017, disetujui April 2017, diterbitkan Juni 2017 


\section{PENDAHULUAN}

Menghadapi

persaingan

kehidupan yang sangat kompetitif menyusul berlakunya globalisasi, sangat diperlukan orang - orang yang memiliki daya saing sekaligus daya tahan yang sangat kuat. Perguruan Tinggi sebagai salah satu pihak bertanggung jawab pada peningkatan kualitas sumber daya manusia, dituntut untuk dapat menyikapi dengan tepat dan cepat karena sekarang ini semakin banyak lulusan Perguruan Tinggi yang tidak dapat memperoleh lapangan kerja. Guna mengantisipasi semakin ketatnya kompetisi mencari lapangan kerja, lulusan Perguruan Tinggi selain dituntut berkualitas tinggi, dituntut pula untuk bisa mandiri sebagai enrtepreneur. Seperti yang dikemukakan Alma (2001: 1) bahwa semakin maju suatu negara semakin banyak orang terdidik, dan semakin dirasakan pentingnya dunia entrepreneur.

Seorang entrepreneur adalah seorang yang memiliki kemampuan dalam mengahadapi segala situasi dan kondisi, memilki kompetensi yang tinggi sehingga dapat memecahkan semua masalah yang dihadapi. Ada lima esensi pokok entrepreneur adalah (1) Kemauan yang kuat untuk berkarya dan selalu bersemangat (2) Kemauan memecahkan masalah dan membuat keputusan yang sistematis serta dapat mengambil resiko (3) Kemauan berfikir dan bertindak secara kreatif dan inovatif (4) Kemauan kerja yang teliti, tekun dan produktif (5) Kemauan bersaing secara sehat ( Soeharto Prawiro, 1997).

Demi menjaga kepercayaan masyarakat maka Perguruan Tinggi harus dapat mengusahakan para lulusannya siap menjadi pekerja atau pegawai negeri maupun siap sebagai entrepreneur. Mahasiswa perlu disadarkan bahwa peluang mencari kerja harus diubah menjadi peluang menciptakan kerja, minimal bagi diri sendiri. Untuk itu Perguruan Tinggi harus senantiasa akuntabel pada publik, ini dicerminkan dalam bentuk peningkatan kualitas, relevansi dan efisiensi. Kualitas kaitannya dengan proses pendidikan untuk menghasilkan lulusan yang profesional, antara lain dengan kurikulum yang baik dan didukung dengan Sumber Daya Manusia yang berkualitas juga dilaksanakan dengan proses pendidikan yang tepat dan efektif. Relevansi berkaitan dengan kesesuaian kurikulum yang diterima mahasiswa dengan kebutuhan dunia kerja pada umumnya. Efisiensi artinya terciptanya efektivitas dalam proses pendidikan untuk mencapai hasil yang optimal.

Sekarang ini Perguruan Tinggi harus sudah mengimplementasikan kurikulum KKNI, Di Universitas Muhammadiyah Magelang kurikulum tersebut diberlakukan untuk mahasiswa baru, dimana dalam kurikulum tersebut mahasiswa diberikan tambahan materi perkuliahan yang dianggap dapat 
mempersiapkan para lulusan dapat bersaing di dunia kerja dan menyiapkan lapangan kerja bagi dirinya maupun bagi orang lain. Salah satu materi tersebut adalah tentang entrepreneurship. Pengetahuan tentang entrepreneurship diberikan dalam bentuk mata kuliah dengan jumlah SKS tertentu .

Entrepreneurship merupakan padanan kata dari kewirausahaan. Kata entrepreneurship berasal dari bahasa Perancis entreprende yang berarti petualang, pencipta dan pengelola usaha. Istilah tersebut di perkenalkan pertama kali oleh Richard Cantilon ( 1755 )

Secara terminologi, David E.Rye dalam bukunya The Veet Pocket Entrepreneur (1996), mempresentasikan kewirausahaan sebagai pengetahuan terapan dari konsep dan teknik manajerial yang disertai resiko dalam mentransformasi sumberdaya menjadi output yang memiliki nilai tambah tinggi (value added) .

Secara

epistimologi, kewirausahaan merupakan suatu nilai yang diperlukan untuk memulai sesuatu usaha (start-up phase) atau suatu proses dalam mengerjakan suatu yang baru (creative) dan sesuatu yang berbeda (inovative) P. Drucker (1996: 20) menyatakan bahwa kewirausahaan adalah suatu kemampuan untuk menciptakan suatu yang baru dan berbeda (ability to create the new and different ).
Kao (Rambat Lupiyoadi, 2004: 3), kewirausahaan sebagai suatu proses, yaitu proses penciptaan sesuatu yang baru (kreasi baru) dan membuat sesuatu yang berbeda dari yang sudah ada (inovasi) tujuannya adalah tercapainya kesejahteraan individu dan nilai tambah bagi masyarakat. Sedangkan wirausaha mengacu pada orang yang melaksanakan proses penciptaan kesejahteraan atau kekayaan dan nilai tambah melalui peneloran dan penetasan gagasan, memadukan sumber daya dan merealisasikan gagasan tersebut menjadi kenyataan.

Dari beberapa pendapat tersebut diatas dapat dipahami bahwa entrepreneurship atau kewirausahaan merupakan proses mengidentifikasi, mengembangkan, dan menciptakan usaha baru yang bersifat inovatif dalam rangka meningkatkan pendapatan di dalam kegiatan usahanya. Kewirausahaan dipandang sebagai fungsi yang mencakup eksploitasi peluang yang muncul di pasar kehidupan. Eksploitasi tersebut sebagian besar berhubungan dengan pengarahan dan atau kombinasi inputoutput yang lebih produktif dan bermakna.

Adapun mahasiswa yang memiliki ciri kepribadian entrepreneurship adalah 1) memiliki cita-cita yang tinggi, 2) berani menanggung resiko, 3) bekerja keras dan memiliki samangat kerja yang tinggi, 4) rasa percaya yang tinggi, 5) memiliki ketrampilan dalam 
memimpin orang lain, 6) bersifat jujur, 7) bersikap mandiri, 8) disiplin Kepribadian .

$$
\text { Bimbingan kelompok }
$$
merupakan bantuan terhadap individu yang dilaksanakan dalam situasi kelompok. Bimbingan kelompok dapat berupa penyampaian informasi ataupun aktifitas kelompok membahas masalah-masalah pendidikan, pekerjaan, pribadi dan sosial (dalam Norihsan, 2003: 23). Menurut Sukardi (2002: 48) bimbingan kelompok adalah layanan yang memungkinkan sejumlah individu secara bersamasama memperoleh bahan dari nara sumber yang berguna untuk menunjang kehidupan sehari-hari individu sebagai anggota keluarga, dan masyarakat serta untuk mempertimbangkan dalam mengambil keputusan.

Bimbingan kelompok dilakukan dalam suasana kelompok dengan pemberian bimbingan dan informasi yang nantinya akan membantu mahasiswa menyusun rencana dalam membuat keputusan yang tepat sehingga diharapkan akan berdampak positif bagi mahasiswa dalam kehidupannya dimasa yang akan datang. Kegiatan ini juga diharapkan mendukung optimalnya potensi mahasiswa karena bimbingan kelompok merupakan suatu kegiatan yang mengandung unsur pedagogis yang memanfaatkan dinamika kelompok sehingga pemimpin kelompok bisa melakukan pendekatan secara personal terhadap anggota lain didalam kelompok. Sementara menurut Dewa Ketut Sukardi (2008: 64) bimbingan kelompok yaitu layanan bimbingan yang memungkinkan sejumlah individu secara bersama-sama memperoleh berbagai bahan dari nara sumber tertentu yang berguna untuk menunjang kehidupan sehari-hari baik sebagai individu maupun sebagai, anggota keluarga dan masyarakat serta untuk pertimbangan dalam pengambilan keputusan.

Dinamika kelompok sengaja ditumbuh kembangkan dalam bimbingan kelompok, karena dinamika kelompok adalah hubungan interpersonal yang ditandai dengan semangat, kerja sama antar anggota kelompok, saling berbagi pengetahuan, pengalaman dan mencapai tujuan kelompok. Hubungan yang interpersonal inilah yang nantinya akan mewujudkan rasa kebersamaan diantara anggota kelompok, menyatukan kelompok untuk dapat lebih menerima satu sama lain lebih saling mendukung dan cenderung untuk membentuk hubungan yang berarti dan bermakna didalam kelompok. Dinamika kelompok merupakan jiwa yang menghidupkan dan menghidupi suatu kelompok.

Melalui bimbingan kelompok ini diharapkan akan meningkatkan pemahamana mahasiswa tentang entrepreneurship. Pelaksanaan bimbingan kelompok yang menekannkan adanya dinamika 
kelompok akan memberikan keluasan mahasiswa dalam berpendapat, berargumen sehingga makna entrepreneur dapat diterima dengan maksimal.

\section{METODE PENELITIAN}

Penelitian ini dilakukan pada mahasiswa program studi Bimbingan dan Konseling Fakultas Keguruan dan Ilmu Pendidikan Universitas Muhammadiyah Magelang. Metode pengumpulan data menggunakan observasi dan kuesioner. Sebelum dilaksanakan pengumpulan data instrumen tersebut di tryoutkan kemudian dilakuka uji validasi dan reliabilitas. Metode dalam penelitian ini menggunakan Kuantitatif Deskriptif.

Langkah pertama yang dilakukan peneliti dalam persiapann penelitian adalah survey. Survey dimaksudkan untuk mengamati obyek secara lebih dekat dan mencari informasi kemungkinan pengadaan penelitian di lembaga pendidikan tersebut. Sebagai obyek penelitian peneliti memilih mahasiswa Program studi Bimbingan dan Konseling Universitas Muhammadiyah Magelang sebagai populasinya. Sedang untuk sampel diambil sejumlah siswa dari jumlah populasi atau sejumlah 35 siswa. Teknik yang digunakan dalam penelitian ini adalah teknik Non Random Sampling, dengan metode sampling yang digunakan adalah Purposive Sampling, dimana Purposive Sampling adalah teknik pengumpulan sampel yang didasarkan atas jumlah sampel yang telah di tetapkan oleh peneliti karena beberapa pertimbangan (Suharsimi, 1997), berupa waktu, jumlah populasi yang sangat besar.

Dalam penentuan jadwal penelitian, peneliti bekerja sama di laksanakan setelah kegiatan perkuliahan selesai. Setelah ditentukan jumlah sampelnya, maka angket penelitian di gandakan sejumlah sampel yang akan di isi oleh mahasiswa yang dipilih menjadi responden. Setelah persiapan penelitian sudah terlaksana, maka peneliti segera melanjutkan dengan pengumpulan data melalui angket. Angket penelitian terdiri dari angket pemahaman tentang enterpreneurship. Peneliti menyediakan lembar jawaban yang menyatu dengan lembar pernyataan dimana dalam kolom jawaban terdapat 4 (empat) alternatif jawaban yang dapat dipilih oleh responden. Angket tersebut dibagikan kepada responden secara bertahap dan Sebelum pengisian angket terlebih dahulu peneliti membacakan petunjuk umum pengisian angket, kemudian responden di berikan kesempatan untuk mengerjakan. Pelaksanan eksperimen dilakukan dengan PreTest, Treatment (pemberian layanan bimbingan kelompok), dan Post-Test.

Setelah responden selesai mengerjakan, peneliti segera memeriksa lembar jawaban. Kemudian memberikan skor pada jawaban yang ada. Melalui pemberian 
skor ini maka peneliti mendapatkan data yang berupa angka yang kemudian digunakan sebagai perhitungan statistik.

Instrumen yang akan digunakan terlebih dahulu di uji coba untuk mengetahui validitas (kesahihan) dan tingkat keandalan (reliabilitas). Sedangkan cara subyek untuk uji coba instrument adalah menetapkan dulu yang akan dijadikan sampel. Uji coba instrumen dikenakan kepada 43 mahasiswa semester VI BK FKIP UMMagelang. Suharsimi (2012: 158) mengemukakan bahwa uji validitas instrument adalah suatu teknik pengujian untuk mengetahui tingkat kesahihan dan keandalan suatu insrumen. Tinggi rendahya validitas insrumen menunjukkan sejauh mana data yang terkumpul tidak menyimpang dari gambaran dan tentang variabel yang dimaksud. Sisi lain dari pengertian validitas adalah aspek kecermatan pengukuran. Suatu alat ukur yang valid, tidak sekedar mampu mengugkapkan data dengan tepat akan tetapi juga harus memberikan gambaran yang cermat mengenai data tersebut. Cermat berarti pengukuran itu mampu memberikan gambaran mengenai perbedaan yang sekecil-kecilna diantara subyek yang satu dengan yang lainnya. Pengujian validitas data bertujuan untuk memastikan bahwa masing-masing pertanyaan akan terklarifikasi pada variabel yang telah ditentukan. pengujian kualitas data dilakukan dengan uji validitas dan reabilitas data.

Menurut Suharsimi (2012: 168), reliabilitas menunjukkan pada pengertian suatu instrument cukup dapat di percaya untuk digunakan atau di pakai sebagai alat pengumpulan data karena instrument tersebut sudah baik. Instrument yang baik tidak akan bersifat tendensius, mengarahkan responden untuk memilih jawaban jawaban itu apabila di atasnya memang benar-benar sesuai dengan kenyatan, maka beberapa kalipun akan tetap sama. Hasil uji validitas dan reliabilitas instrument dengan menggunakan program SPSS versi 17.0 for windows, angket motivasi berprestasi yang terdiri dari 47 item pernyataan, 41 pernyataan dinyatakan valid dan 6 item pernyataan dinyatakan gugur.

Tabel 1. Hasil Uji validitas Instrumen

\begin{tabular}{|c|c|c|c|c|c|}
\hline \multirow{2}{*}{ Variabel } & \multicolumn{3}{|c|}{ Jumlah Item } & \multirow{2}{*}{ Item gugur } & \multirow{2}{*}{ Keterangan } \\
\hline & Semua & Valid & Gugur & & \\
\hline $\begin{array}{l}\text { Pemahaman } \\
\text { Enterpreneurshi } \\
p\end{array}$ & 47 & 41 & 6 & $\begin{array}{c}1,9,15,23,35,4 \\
0\end{array}$ & Gugur \\
\hline
\end{tabular}

sebagai instrumen, maka dalam hal ini peneliti menggunakan teknik Product 
Moment yang pengerjaannya dibantu oleh program SPSS Versi 17.00. Uji signifikansi dilakukan dengan membandingkan nilai $r_{\text {observasi }}$ dan $r_{\text {tabel }}$ untuk df $=n-2$, dalam hal ini $\mathrm{n}$ adalah jumlah sampel item, dengan alpha 0,05. Jika $r_{\text {observasi }}>r_{\text {tabel, maka butir }}$ pertanyaan tersebut dikatakan valid (Hartono, 2004: 79). Pengujian validitas pada tahap uji coba dengan sampel sejumlah 47 item, maka nilai df dapat dihitung $47-2=45$, dengan $\mathrm{df}=45$ didapat $\mathrm{r}_{\text {tabel }}$ 0,288. Hal ini berarti bahwa apabila $r_{\text {observasi }}>r_{\text {tabel }}$ yaitu 0,288 maka butir pertanyaan pada kuesioner dapat dikatakan valid.

Menguji reliabilitas instrumen, maka dalam hal ini peneliti menggunakan suatu program SPSS Versi 17.00 yang pengerjaannya dibantu oleh komputer. Reliabilitas instrumen diuji dengan menghitung cronbach alpha instrumen dari masing-masing variabel. Hasil dari perhitungan tingkat pemahaman enterpreneurship tersebut merupakan hasil koefisien alpha dan bila dibandingkan dengan nilai table product moment taraf $5 \%$ sama dengan 0,288. Jika koefisien alpha pada variabel lebih besar dari nilai tabel maka artinya instumen tersebut reliabel. Hasil perhitungan uji reliabilitas dapat dilihat di bawah ini :

Tabel 2. Hasil Uji Reliabilitas Instrumen

\begin{tabular}{|l|c|c|c|}
\hline \multicolumn{1}{|c|}{ Variabel Penelitian } & Nilai r Alpha & Nilai r Tabel & $\begin{array}{c}\text { Keteranga } \\
\mathrm{n}\end{array}$ \\
\hline $\begin{array}{l}\text { Pemahaman } \\
\text { Enterpreneurship }\end{array}$ & 0,943 & 0,288 & Handal \\
\hline
\end{tabular}

Analisis yang dilakukan ini bertujuan untuk membuktikan atau menguji hipotesis yang di kemukakan sebelumnya. Adapun teknis analisis data yang digunakan menggunakan bantuan SPSS versi 17.0 untuk mempermudah perhitungan data yang didapatkan. Setelah diperoleh data penelitian baik data pre-test dan posttest, maka langkah selanjutnya adalah melakukan analisis data. Analisis data ingin digunakan untuk menguji hipotesis yang di ajukan sebelumnya.

Hasil pengujian hipotesis tersebut, selanjutnya akan digunakan sebagai pembahasan permasalahan yang ada. Paired Sample T-test adalah uji yang dilakukan terhadap dua sampel yang berpasangan (paired). Sampel yang berpasangan diartikan sebagai sebuah sampel dengan subyek yang sama, namun mengalami dua perlakuan atau pengukuran yang berbeda.

\section{PEMBAHASAN}

Analisis data ini digunakan untuk menguji hipotesis yang diajukan 
sebelumnya. Hasil pengujian tersebut, selanjutnya akan digunakan sebagai pembahasan permasalahan yang ada. Hasil analisis data dapat diketahui dalam penelitian ini terdapat hipotesis yang diuji secara statistik, yaitu: "Terdapat perbedaan yang meyakinkan antara pemahaman enterpreneurship mahasiswa sebelum mendapatkan perlakuan layanan bimbingan kelompok dengan pemahaman enterpreneurship mahasiswa yang sudah mendapat perlakuan di Prodi BK FKIP UMMagelang”.

Tabel 3. Paired Sample Test

Paired Samples Test

\begin{tabular}{|c|c|c|c|c|c|c|c|c|}
\hline & \multicolumn{5}{|c|}{ Paired Differences } & \multirow[b]{3}{*}{$t$} & \multirow[b]{3}{*}{$d f$} & \multirow[b]{3}{*}{ Sig. (2-tailed) } \\
\hline & \multirow[b]{2}{*}{ Mean } & \multirow[b]{2}{*}{ Std. Deviation } & \multirow{2}{*}{$\begin{array}{l}\text { Std. Error } \\
\text { Mean }\end{array}$} & \multicolumn{2}{|c|}{$\begin{array}{l}95 \% \text { Confidence } \\
\text { Interval of the } \\
\text { Difference }\end{array}$} & & & \\
\hline & & & & Lower & Upper & & & \\
\hline $\begin{array}{ll}\text { Pair } & \text { sebelum perlakuan } \\
1 & \text { - setelah perlakuan }\end{array}$ & -5.743 & 5.221 & .882 & -7.536 & -3.949 & -6.508 & 34 & .000 \\
\hline
\end{tabular}

\section{Interpretasi Output Paired Samples} test.

Untuk Menguji adakah ada perbedaan signifikan rata-rata skor pemahaman enterpreneurship sebelum dan setelah pemberian Layanan Bimbingan Kelompok, maka dapat dilakukan penyusunan hipotesis yang dirumuskan untuk menguji perbedaan mean atau rata-rata hitung, yaitu:

1. Keputusan I. Tampak pada tabel Paired sample-test bahwa nilai $\mathrm{t}$ hitung adalah $\mathrm{t}=-6.508$ dengan $\mathrm{p}$ $=0.00$. Oleh karena $\mathrm{p}<0.05$, maka Ho ditolak atau kedua rata-rata populasi tidak sama

2. Pengambilan Keputusan II. Pengambilan keputusan juga dapat dilakukan dengan cara membandingkan nilai $\mathrm{t}$ hitung dengan $t$ tabel, dengan ketentuan: a. Jika $\pm \mathrm{t}_{\text {hitung }}< \pm \mathrm{t}_{\text {tabel }}$, maka $\mathrm{H}_{\mathrm{o}}$ diterima dan $\mathrm{H}_{\mathrm{a}}$ ditolak

b. Jika $\pm \mathrm{t}_{\text {hitung }}> \pm \mathrm{t}_{\text {tabel }}$ maka $\mathrm{H}_{\mathrm{o}}$ ditolah dan $\mathrm{H}_{\mathrm{a}}$ diterima

3. Keputusan II. Tampak Bahwa $t_{\text {hitung }}$ $=-6.085$ Dan $t_{\text {tabel }}$ (pada tabel distribusi nilai $\mathrm{t}$ ), yaitu pada taraf kepercayaan $95 \%$ pada derajat bebas $(\mathrm{df})=\mathrm{n}-1=35-1=34$, sehingga $t_{\text {tabel }}$ pada df $34=2.05$. Jika $t_{\text {hitung }}>\mathrm{t}_{\text {tabel }}$ atau di luar daerah penerimaan Ho, maka diputuskan ho ditolak.

\section{Efektivitas Pelayanan Bimbingan Kelompok.}

Untuk dapat menyimpulkan efektif tidaknya pelayanan Bimbingan kelompok yang telah dilakukan terhadap responden, peneliti mendasarkan pada argumen yang dibangun, yakni: Layanan dapat 
dikatakan efektif jika dominan responden mengalami kenaikan skor pemahaman enterpreneurship setelah dilakukan perlakuan.

Dalam hasil analisis terbukti terdapat peningkatan rata-rata pemahaman enterpreneurship siswa dalam angket pre-test dan post-test; jadi ada pengaruh pemahaman enterpreneurship Melalui Layanan Bimbingan Kelompok. Bukti peningkatan pemahaman enterpreneurship dapat di lihat dalam tabel skor atau perbandingan antara hasil pre-test dan hasil post-test.

Tabel 4. Kenaikan dan Penurunan Skor pemahaman enterpreneurship Sebelum dan Sesudah Perlakuan

\begin{tabular}{|c|c|c|c|c|}
\hline $\begin{array}{c}\text { Responde } \\
\text { n }\end{array}$ & $\begin{array}{c}\text { Pre } \\
\text { Treatmen }\end{array}$ & $\begin{array}{c}\text { Post } \\
\text { Treatmen }\end{array}$ & $\begin{array}{c}\text { Nilai } \\
\text { Kenaikan } \\
(+) / \text { Penurunan } \\
(-) \\
\end{array}$ & $\begin{array}{c}\text { Prosentase (\%) } \\
\text { Kenaikan (+) } \\
\text { /Penurunan (-) }\end{array}$ \\
\hline 1 & 120 & 139 & 19 & 15.8 \\
\hline 2 & 122 & 126 & 4 & 3.2 \\
\hline 3 & 111 & 120 & 9 & 8.1 \\
\hline 4 & 109 & 110 & 1 & 0.9 \\
\hline 5 & 126 & 131 & 5 & 3.9 \\
\hline 6 & 114 & 115 & 1 & 0.9 \\
\hline 7 & 114 & 113 & -1 & -0.9 \\
\hline 8 & 126 & 124 & -2 & -1.6 \\
\hline 9 & 120 & 120 & 0 & 0 \\
\hline 10 & 118 & 111 & -7 & -5.9 \\
\hline 11 & 121 & 123 & 2 & 1.7 \\
\hline 12 & 110 & 115 & 5 & 4.5 \\
\hline 13 & 124 & 136 & 12 & 9.7 \\
\hline 14 & 106 & 110 & 4 & 3.8 \\
\hline 15 & 108 & 117 & 9 & 8.3 \\
\hline 16 & 123 & 131 & 8 & 6.5 \\
\hline 17 & 114 & 122 & 8 & 7 \\
\hline 18 & 117 & 122 & 5 & 4.3 \\
\hline 19 & 112 & 118 & 6 & 5.4 \\
\hline 20 & 105 & 114 & 9 & 8.6 \\
\hline 21 & 114 & 131 & 17 & 14.9 \\
\hline 22 & 112 & 120 & 8 & 7.1 \\
\hline 23 & 121 & 125 & 4 & 3.3 \\
\hline 24 & 115 & 125 & 10 & 8.7 \\
\hline 25 & 114 & 119 & 5 & 4.4 \\
\hline 26 & 110 & 123 & 13 & 11.8 \\
\hline 27 & 112 & 114 & 2 & 1.8 \\
\hline
\end{tabular}




\begin{tabular}{|c|c|c|c|c|}
\hline $\begin{array}{c}\text { Responde } \\
\mathbf{n}\end{array}$ & $\begin{array}{c}\text { Pre } \\
\text { Treatmen }\end{array}$ & $\begin{array}{c}\text { Post } \\
\text { Treatmen }\end{array}$ & $\begin{array}{c}\text { Nilai } \\
\text { Kenaikan } \\
(+) / \text { Penurunan } \\
(-)\end{array}$ & $\begin{array}{c}\text { Prosentase (\%) } \\
\text { Kenaikan (+) } \\
\text { /Penurunan (-) }\end{array}$ \\
\hline 28 & 116 & 122 & 6 & 5.2 \\
\hline 29 & 124 & 126 & 2 & 1.6 \\
\hline 30 & 126 & 132 & 6 & 4.8 \\
\hline 31 & 113 & 115 & 2 & 1.8 \\
\hline 32 & 115 & 126 & 11 & 9.6 \\
\hline 33 & 111 & 116 & 5 & 4.5 \\
\hline 34 & 112 & 115 & 3 & 2.7 \\
\hline 35 & 114 & 124 & 10 & 8.8 \\
\hline Rata-Rata & $\mathbf{1 1 5 . 6 8 5 7 1}$ & $\mathbf{1 2 1 . 4 2 8 6}$ & $\mathbf{5 . 7 4 2 8 5 7 1 4 3}$ & $\mathbf{4 . 9 6}$ \\
\hline
\end{tabular}

Dari tabel di atas terlihat bahwa sebanyak 32 mahasiswa mengalami kenaikan pemahaman enterpreneurship dan sebanyak 3 siswa mengalami penurunan, dari rata seluruh responden terlihat bahwa rata- rata siswa mengalami kenaikan pemahaman enterpreneurship 91,4\% dan mengalami penurunan sebesar 8,6\%. Untuk lebih memudahkan membaca hasil analisis disajikan dalam tabel seperti dibawah ini:

Tabel 5. Presentase Kenaikan dan Penurunan Pemahaman Enterpreneurship

\begin{tabular}{|l|c|c|}
\hline \multicolumn{1}{|c|}{ Siswa } & Jumlah & Prosentase \\
\hline $\begin{array}{l}\text { Jumlah siswa yang mengalami } \\
\text { kenaikan skor }\end{array}$ & 32 & 91,4 \\
\hline $\begin{array}{l}\text { Jumlah siswa yang mengalami } \\
\text { penurunan skor }\end{array}$ & 3 & 8,6 \\
\hline Jumlah & $\mathbf{3 5}$ & $\mathbf{1 0 0 \%}$ \\
\hline
\end{tabular}

Dari prosentase kenaikan dan penurunan pemahaman enterpreneurship tersebut terlihat bahwa dominan responden mengalami kecenderungan kenaikan pemahaman enterpreneurship sebanyak 32 dari 35 responden (atau sebesar 91.4\%) setelah mendapatkan layanan bimbingan kelompok. Berdasarkan jumlah angka di atas peneliti berani menyimpulkan bahwa perlakuan pelayanan bimbingan dapat dikatakan efektif.

\section{KESIMPULAN}

Berdasarkan penelitian dalam rangka pembahasan dapat diambil kesimpulan bahwa terdapat perbedaan pemahaman enterpreneurship mahasiswa sebelum dan sesudah perlakuan atau treatment layanan bimbingan kelompok. Hal ini terbukti hasil uji statistics paired sample test dengan program SPSS, di dapatkan 
hasil $T$-test $=-6.085$ dengan $\mathrm{p}=0.00$. Oleh karena $\mathrm{p}<0.05$, maka Ho ditolak atau kedua rata-rata populasi tidak sama.dari hasil pengujian $\mathrm{t}$ tabel $\mathrm{di}$ dapatkan Tampak Bahwa $t_{\text {hitung }}=$ -6.085 Dan $t_{\text {tabel }}$ (pada tabel distribusi nilai t), yaitu pada taraf kepercayaan 95\% pada derajat bebas (df) $=\mathrm{n}-1=$ $35-1=34$, sehingga $t_{\text {tabel }}$ pada df $34=$ 2.05. Jika $t_{\text {hitung }}>t_{\text {tabel }}$ atau di luar daerah penerimaan Ho, maka diputuskan Ho ditolak. Dari hasil pengecekan $t_{\text {hitung }}$ dengan $t_{\text {tabel }}$ diketahui: $\mathrm{t}_{\text {hitung }}=-6.085>\mathrm{t}_{\text {tabel }}=$ -0.205, maka $\mathrm{H}_{\mathrm{o}}$ ditolak dan $\mathrm{H}_{\mathrm{a}}$ diterima.

Perlakuan melalui layanan bimbingan kelompok di mahasiswa prodi BK FKIP UMMagelang dapat dikatakan efektif di dasarkan pada argumen bahwa pemahaman enterpreneurship yang menjadi responden dominan mengalami peningkatan motivasi berprestasi yakni sebanyak 32 siswa (91,4\%), sedang yang mengalami penurunan sebanyak 3 siswa $(8,6 \%)$.

\section{DAFTAR PUSTAKA}

Alma, Buchari, 2007. Kewirausahaan, Bandung, Alfabeta.
Adi Sutanto, 2002. Kewirausahaan, Jakarta : Ghalia Indonesia.

Muladi Wibowo, 2011. Pembelajaran kewirausahaan dan minat wirausaha lulusan SMK. Jurnal ekspansi volume 6 nomor 2 edisi September 2011.

Ronstad, Robert C, 1984. Entrepreneurship, Lord Publishing Company Denverma.

Santoso, Singgih dan Fandy Tjiptono, 2001. Riset Pemasaran : Konsep dan Aplikasi dengan SPSS. Jakarta : Penerbit Elex Media Komputindo.

Suryana, 2008. Kewirausahaan, Salemba empat. Jakarta. Yogyakarta: Fakultas Ekonomi Universitas Gajah Mada.

Winardi, 2005. Entrepreneur \& Entrepreneurship, Jakarta: Prenada Media Kencana.

Zimmer, Thomas W., Norman M. Scarborough, 2002. Essentials of Entrepreneurship and Small Management, New Jersey: Pearson Education. 